\title{
Summer season variability of dissolved oxygen concentration in Antarctic lakes rich in cyanobaterial mats
}

\author{
Peter Váczi*, Miloš Barták \\ Laboratory of Photosynthetic Processes, Section of Plant Physiology, Department of \\ Experimental Biology, Masaryk University, Kamenice 5, 62500 Brno, Czech Republic
}

\begin{abstract}
Since 2007, limnological investigation of terrestrial lakes has been carried out at James Ross Island, Antarctica. The lakes in scope differ in their size, origin, geomorphological and hydrological characteristics. In several selected lakes, dissolved oxygen is measured repeatedly each summer season in order to quantify lake- and weather-related differences. For this study, typical reresentatives of (i) coastal shalow lakes, and (ii) high-altitude lakes with cyanobacterial mats were chosen. We present data on dissolved oxygen measured in $3 \mathrm{~d}$ interval during January 2010. Within this time, water temperature decreased gradually from 13 to $3^{\circ} \mathrm{C}$, as well as dissolved oxygen concentration. It varied within in the range of $12.50-18.0 \mathrm{mg} \mathrm{l}^{-1}$ indicating the values close to saturation and suprasaturation, respectively. Dissolved oxygen concentration showed slightly decreasing trend in a course of time. In majority of cases, the lakes with rich cyanobacterial flora showed higher dissolved oxygen concentrations than Lachman Lake 2 which posses less cyanobacterial mats than other the lakes involved into the study. Due to air temperature decrease, Dulanek lake, a high-altitude lake, froze in the last week of January 2010.
\end{abstract}

Key words: James Ross Island, Lachman Lake 2, oxygen

\section{Introduction}

The relationships between algal and cyanobacterial mats in Antarctic lakes and limnological features of particular lakes have been studied in several parts of Antarctica. Geographically, the studies focused mainly on the lakes at McMurdo Dry Valleys area (Hawes 1993, Vincent et al. 1993, Moorhead et al. 2005), Vestfold Hills (Laybourn-Parry et Marchant, 1992), South Shetland Islands and Antarctic Peninsula (Vinocur et Pizarro 2000).
Majority of limnological studies have been related mainly to species richness of cyanobacterial mats and general chemical characteristics of water samples. Therefore, detailed limnological studies published so far have determined many characteristics, such as e.g. $\mathrm{pH}$, conductivity, alkalinity, total dissolved inorganic carbon, $\mathrm{CO}_{2}, \mathrm{HCO}_{3}, \mathrm{NO}_{3}-\mathrm{N}, \mathrm{NO}_{2}-\mathrm{N}, \mathrm{NH}_{4}-$ $\mathrm{N}, \mathrm{PO}_{4}-\mathrm{P}$, total $\mathrm{P}, \mathrm{Ca}, \mathrm{Mg}, \mathrm{K}$, (see e.g. Toro et al. 2006). In spite of the fact, that

Received October 3, 2011, accepted December 2, 2011.

*Corresponding author: vaczi@sci.muni.cz

Acknowledgement: The authors acknowledge the possibility to use J. G. Mendel station infrastructure during the Czech Antarctic Expedition (Jan. - March 2010). 
information on dissolved oxygen concentration in Antarctic lake occured as early as in 1986 (Wharton et al. 1986), only limited number of studies has been published since that time on dissolved oxygen concentration in relation to microbial mat community size and structure, as well as variation of physical factors such as e.g. incident light and water temperature. Amount of dissolved oxygen is considered both biological and physical factors limiting life and development of autotrophic organisms in Antarctic lakes. Actual amount of dissolved oxygen depends mainly on physical and chemical characteristics of water, as well as the development and physiological activity of photosynthetizing microbiota (Montecino et al. 1991). These factors may cause variability of dissolved oxygen within a single austral summer season, when water temperature rises due to full or partial loss of ice and more light availability in water column.

Since a pioneering study on algal community of freshwater streams (Hawes et Brazier 1991), no attempt has been made to study microbial mats and their physiological characteristics at James Ross Island. In 2006, however, Czech research station J.G.Mendel was built and provided its infrastucture for annual summer-season expeditions of Czech and international scientists to James Ross Island. Therefore, cyanobacteria of several lakes and see-

\section{Material and Methods}

\section{Lake characteristics}

Due to colder weather and progressive freezing of water column, only 4 out of the 7 lakes investigated in 2009, were chosen for the measurements in 2010. They are characterized in Table 1. The lakes are located in deglaciated Northern part of James Ross Island. According to geographical location, they may be divided into two subgroups. The first one pages of James Ross Island have been studied since 2006 (e.g. Komárek et al. 2008). Moreover, long-term investigation of lakes focused on major limnological and hydrobiological characteristics started in 2007. Altogether, 16 lakes in the nortern part of James Ross Island have yet been investigated (Nedbalová, Elster, unpublished data). They represented lakes of both small and large areas. The lakes differed also in their character and origin. Most frequent types were (1) flatbottomed lakes on coastal terraces, (2) thermokarst lakes, and (3) corrie lakes. Some of them were frozen with surface and bottom ice in the summer season.

In 2009 summer season (Jan-Feb 2009), variation of dissolved oxygen in 7 lakes of James Ross Island was measured repeatedly to evaluate the differences related to prevailing weather (Váczi et Barták 2009). It was found that dissolved oxygen concentration was reduced by 15 $30 \%$ on overcast days (compared to fully sunny days). In 2010, the same study was performed in the same lakes and even the same sampling sites. We hypothesized that interseasonal diferences in dissolved oxygen may be distinguised if the local weather of 2009 and 2010 austral summer seasons differ. In this paper, we present some detailed information about the investigated lakes as well as variation in oxygen concentration of particular lakes.

comprises Interlago 1, Interlago 2, and Lachman Lake 2 (Small Lachman Lake see References). In fact, small area lakes Interlago 1 and Interlago 2 form a communication between much larger lakes Lachman Lake 1 (Big Lachman Lake - see References) and Lachman Lake 2 (see Figs. 1, 3). All they are situated close to SE coastal line of Cape Lachman, i.e. they 
are distant only $100 \mathrm{~m}$ from the sea. The lakes are located in sedimentary rocks and, on their west side, surrounded by rich moss and lichen vegetation formed in the neighbouring seepages. There are also several skua nestling sites in close neighbourhood of the lakes that provide nutrients to the seepages and lakes.

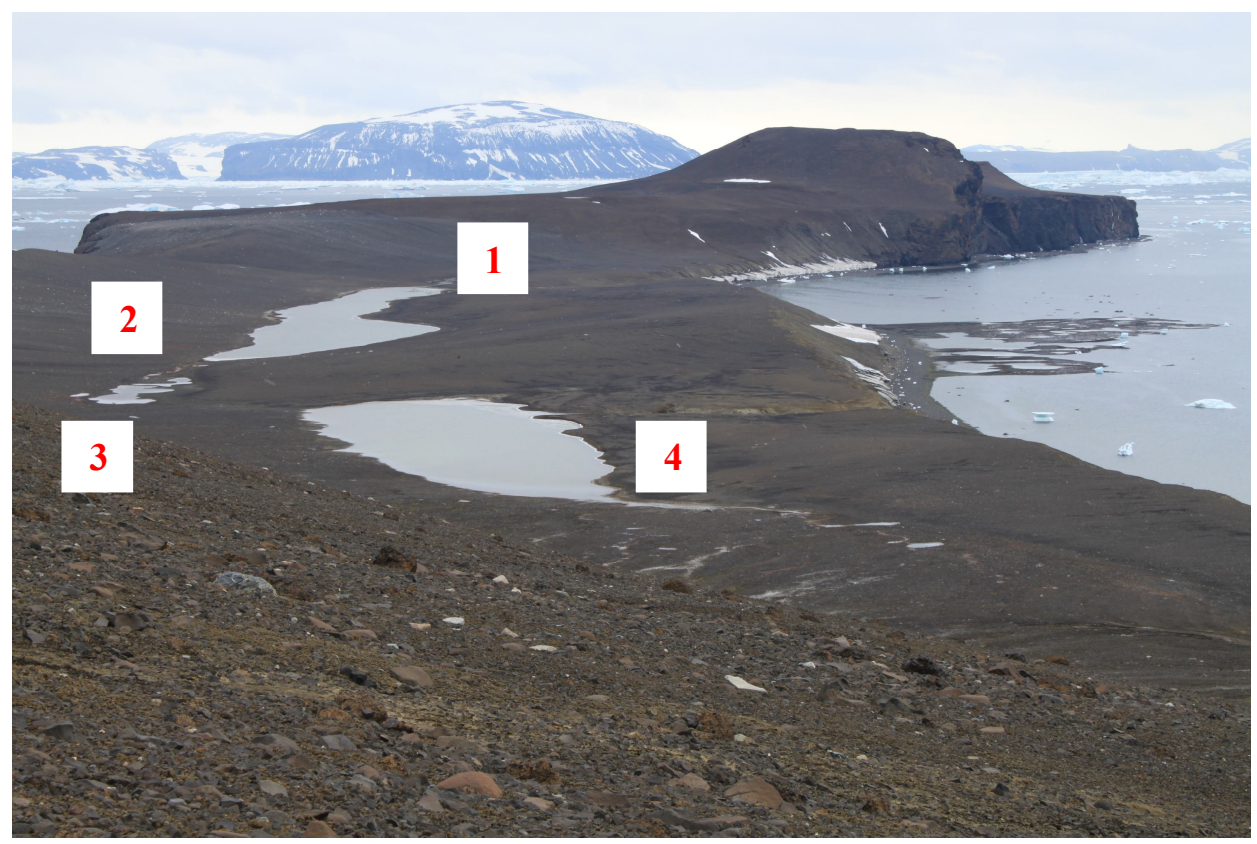

Fig. 1. General view on Cape Lachman with the indication of lakes: (1) Lachman Lake 1 (Big Lachman Lake), (2) Interlago 1, (3) Interlago 2, and (4) Lachman Lake 2 (Small Lachman Lake).

\begin{tabular}{lcccc}
\hline Locality & $\begin{array}{c}\text { Latitude } \\
\text { (South) }\end{array}$ & $\begin{array}{c}\text { Longitude } \\
\text { (West) }\end{array}$ & $\begin{array}{l}\text { Altitude } \\
\text { (m a.s.l.) }\end{array}$ & $\begin{array}{c}\text { Maximum } \\
\text { Depth (m) }\end{array}$ \\
\hline & & & & \\
Interlago 1* & 63.7985567 & 57.8101200 & $12 \mathrm{~m}$ & 0.5 \\
Interlago 2* & 63.7989033 & 57.8104816 & $12 \mathrm{~m}$ & 0.7 \\
Lachman 2* $^{*}$ & 63.7998683 & 57.8087217 & $10 \mathrm{~m}$ & 1.5 \\
Dulanek* & 63.8170399 & 57.8458549 & $220 \mathrm{~m}$ & 1.1 \\
\hline
\end{tabular}

Table 1. Geographical characteristics of the lakes involved into the study. Lake Lachman 2 represents an official geographical name. The other names are provisional, suggested for official geographical nomenclature of the Jamess Ross Island. An arterisk indicates that the name of the lake is provisional.

Lake Dulanek is located nearby Windy Pass at the height of $220 \mathrm{~m}$ a.s.l. It is rather a small lake of area of about $25 \mathrm{~m}^{2}$ formed in a shallow depression at a SE- facing foothill of the Lachman Crags mesa (Fig. 2). The depth of water column varies within a season, it is about $1.1 \mathrm{~m}$ at the begining of austral summer and 0.7 at the 
end of austral summer. Due to neighbouring rock walls it is sun-lit only for a limited period of a day. During austral summer, direct sunshine is available only to $15: 30 \mathrm{~h}$ local time. The lakes are rich in cyanobacterial mats. Especially in the Interlago1, Interlago 2, and Dulanek, lake bottom is fully covered by a cyanobacterial mat (see Fig 3). Dominating matforming specieas are Calothrix sp., Calothrix elsteri, Leptolyngbia antarctica, Hassallia antarctica, Hassallia andreassenii sp. nova as reported by Komárek et Elster (2008), Komárek et al. (2008).

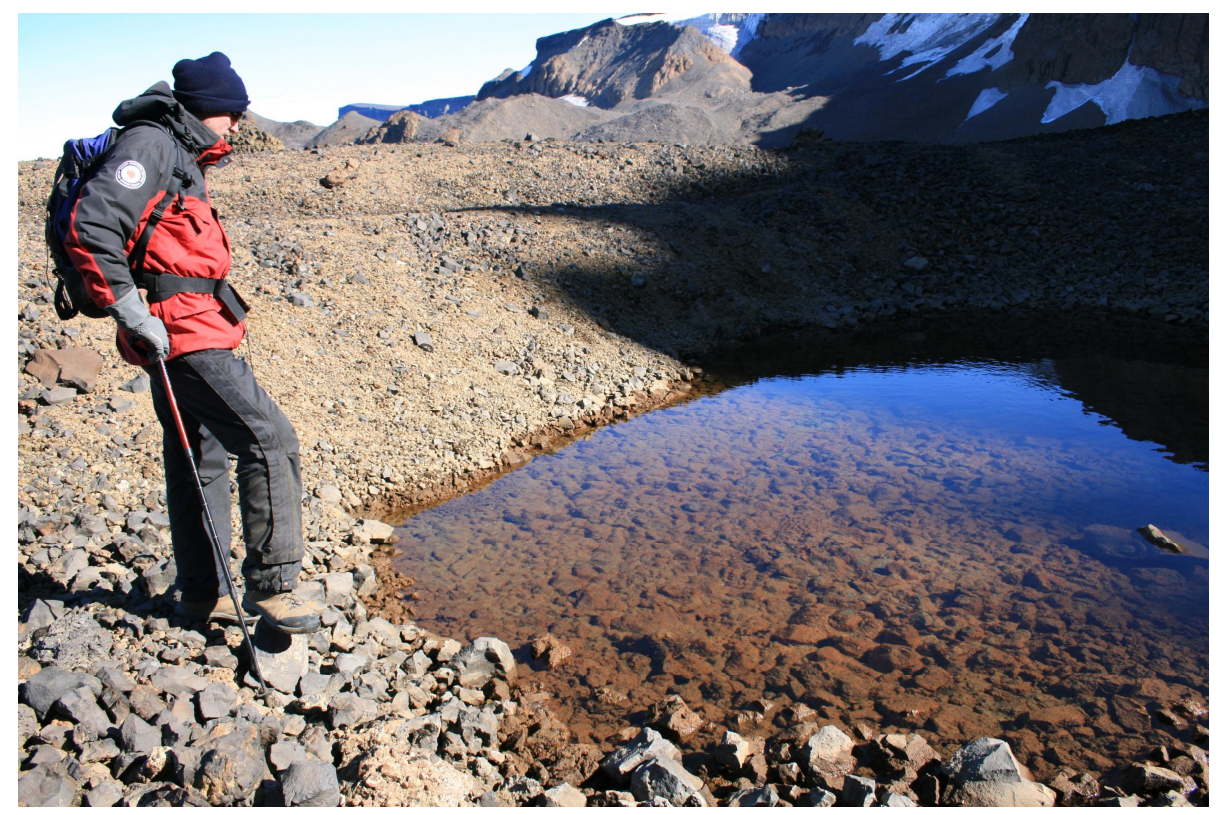

Fig. 2. Dulanek Lake represents an example of smale-area water pool. The bottom is covered by thick cyanobacterial mat.

\section{Dissolved oxygen measurements}

Dissolved oxygen concentration was measured repeatedly in the interval of about $3 \mathrm{~d}$ in January 2010. The measurements were stopped on Jan 30th, when one of the lakes froze to its bottom. The measurements were taken within the period of 10:00 to 14:00 of local time. On each measuring day, the lakes were visited and dissolved oxygend measured in the same sequence of sites: (i) Interlago 1, (ii) Interlago 2, (iii) Lachman Lake 2, (iv) Dulanek. At each site, there were 5-7 sampling sites, location of which was the same as in the former study (Váczi et
Barták 2009). The oxygen concentrations were measured by a portable Oxymeter WTW Oxi 197i equipped with a WTW CellOx 325 electrode. The probe was placed into the depth of about $20 \mathrm{~cm}$ and oxygen concentration measured when an equilibrium (constant value) was reached. Repeated measurements of at least 5 values were recorded for each sampling site. Mean values of dissolved oxygen concentration and water temperature for each sampling site and lake, respectively, were calculated. 


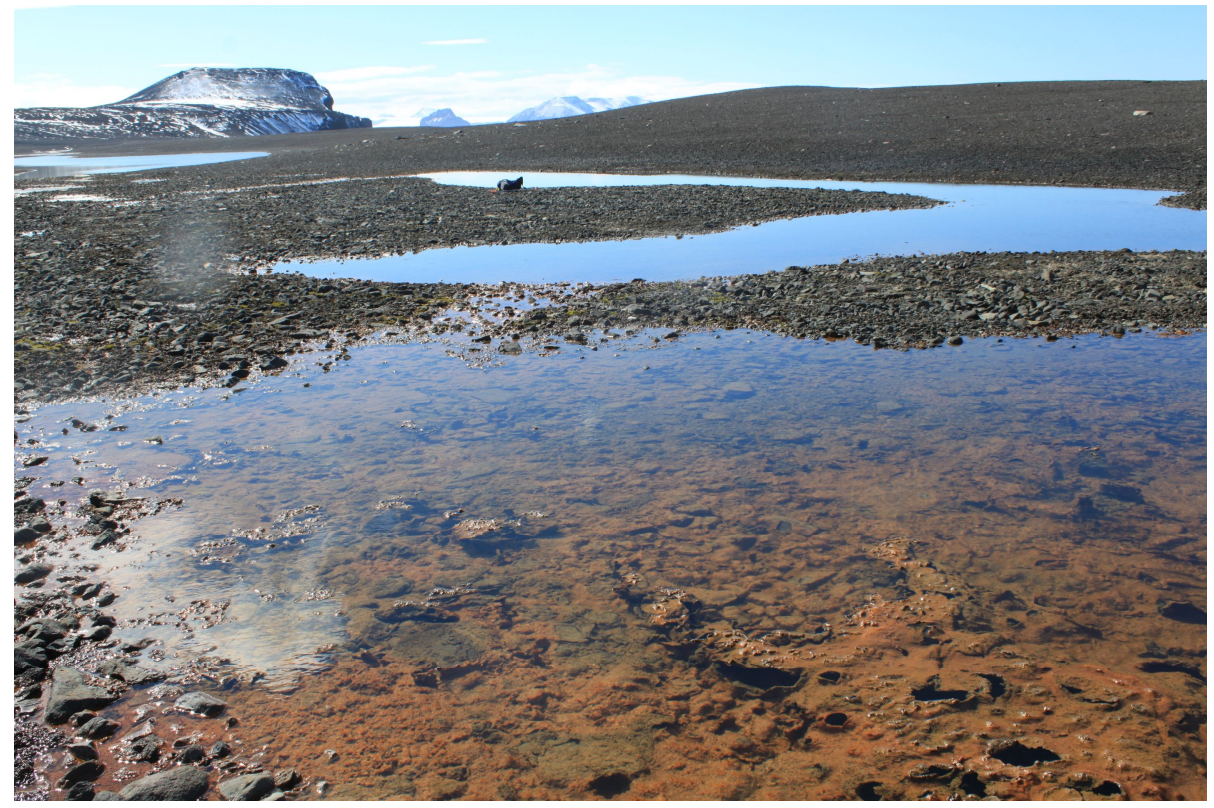

Fig. 3. Cyanobacterial mats formed in Interlago 2 (in front) and Interlago 1 lakes (in the middle).

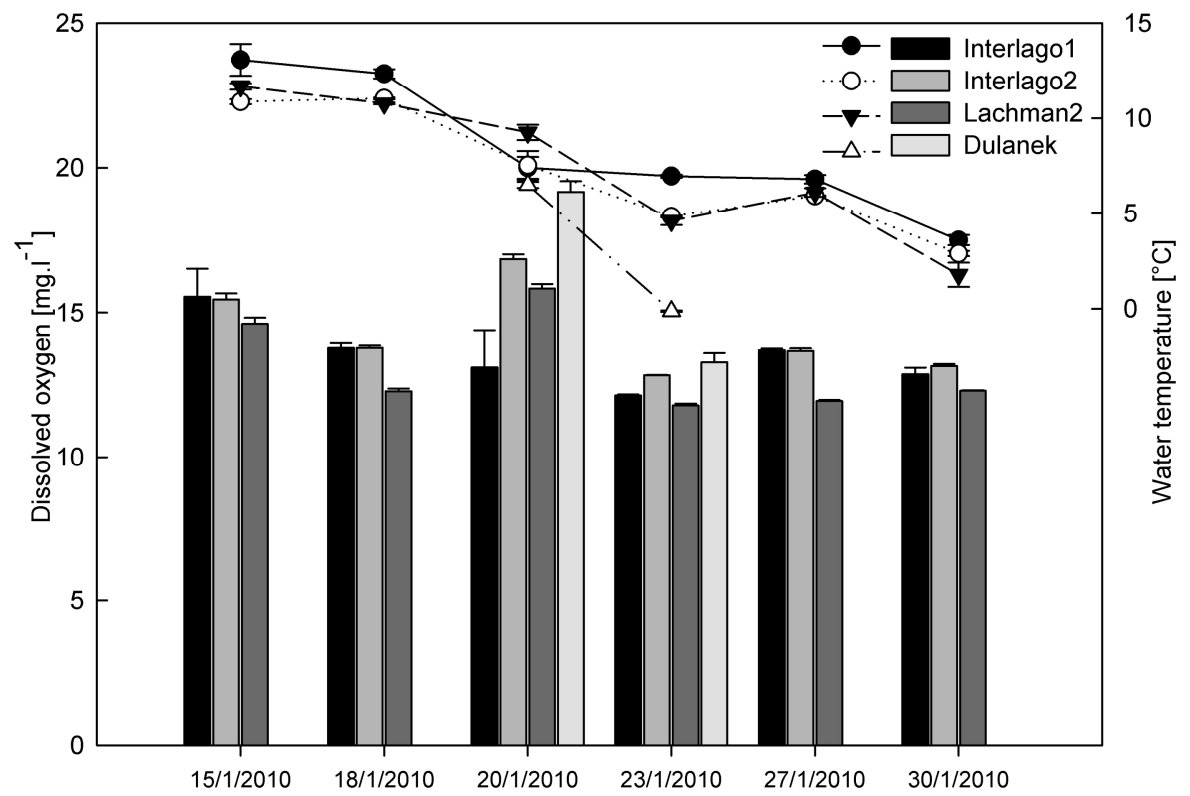

Fig. 4. Oxygen concentrations (bars) and water temperature course (scatter graph) in several lakes at the Northern part of the James Ross Island recorded in January 2010. The values are means of at least 5 replicates. Error bars represent \pm SD. 


\section{Results and Discussion}

Water temperature decreased gradually in all investigated lakes in Jan 2010 (Fig. 4). However, in Dulanek Lake, the rate of derease was higher then in other lakes from Jan 20th. A week later, Dulanek Lake froze completely. It is associated with different geomorphological position of the lakes. While Dulanek Lake is located in $220 \mathrm{~m}$ a.s.l and could be ranked a small unstable lake, the other lakes are shallow coastal lakes that, due to higher air temperature, freeze later. Recently, more detailed data will be available on the process of ice fromation and Dulanek Lake freezing, because there is an automatic measuring system (established in February 2011) recording water temperature profile in Dulanek Lake (M. Bartak, unpublished). For majority of measurements, dissolved oxygen concentrations were higher in the Interlago 1 and Interlago 2 Lakes then in Lachman Lake 2, which was comparable to the data from 2009 austral summer season (Váczi et Barták 2009). Absolute dissolved oxygen values (means for particular date) were slightly higher in $2010\left(12.0-19.0 \mathrm{mg} \mathrm{l}^{-1}\right)$ than in 2009 $\left(11.0-14.5 \mathrm{mg} \mathrm{l}^{-1}\right)$. This indicates, that oxygen was close to saturation point in both austral summer season - it is reported that for majority of Antarctic lakes, the value of $12.0 \mathrm{mg} \mathrm{l}^{-1}$ indicates saturation (Toro et al 2006).

With the exception of Interlago 1 Lake, dissolved oxygen values were found significantly higher on Jan 20th than on other days. This might be attributed to the weather of a fully sunny day. High radiation doses, in spite of a drop in water temperature (c.f. Jan 18th and 20th Fig. 4), caused an increase in dissoved oxygen concentration, similarly to what was evidenced in 2009 (Váczi et Barták 2009).

It can be concluded that the lakes on James Ross Island, due to their geomorphological and hydrological differences, represent an important ecosystem components. Their species richness of cyanobacterial and algal flora makes them attractive objects for further limnological, hydrological, ecophysiological, and photosynthetic studies.

\section{References}

Hawes, I. (1993): Photosynthesis in thick cyanobacterial films: a comparison of annual and perennial Antarctic mat communities. Hydrobiologia, 252: 203-209.

Hawes I, Brazier, P. (1991): Freshwater stream ecosystems of James Ross Island, Antarctica. Antarctic Science 3: 265-271.

Komárek, J., Elster, J. and Komárek, O. (2008): Diversity of the cyanobacterial microflora of the northern part of James Ross Island, NW Weddell Sea, Antarctica. Polar Biology, 31: 853-865.

Komárek, O., Komárek, J. (2010): Diversity and Ecology of Cyanobacterial Microflora of Antarctic Seepage Habitats: Comparison of King George Island, Shetland Islands, and James Ross Island, NW Weddell Sea, Antarctica. In: Seckbach, J., Oren, A. (eds.): Microbial Mats. Modern and Ancient Microorganisms in Stratified Systems. Springer, p. 517-538.

Komárek, J., Nedbalová, L. and Hauer, T. (2011): Phylogenetic position and taxonomy of three heterocytous cyanobacteria dominating the littoral of deglaciated lakes, James Ross Island, Antarctica. Polar Biology, doi 10.1007/s00300-011-1123-x.

Laybourn-Parry, J.E.M., Marchant, H.J. (1992): The microbial plankton of freshwater lakes in the Vestfold Hills, Antarctica. Polar Biology, 12: 405-410. 
Montecino, V., Pizarro G., Cabrera S. and Contreras M.(1991): Spatial and temporal photosynthetic compartments during summer in Antarctic Lake Kitiesh. Polar Biology, 11:371377.

Moorhead, D.L., Wharton, R.A., Jr. (1994): McMurdo LTER: Primary production model of benthic microbial mats in Lake Hoare, Antarctica. Antarctic Journal of the United States, 29: 241-243.

Nedbalová, L., Elster, J., Komárek, J. and Nývlt, D. (2009): Lake ecosystems of James Ross Island: Short characteristics. In: M. Barták, J. Hájek, P. Váczi (eds.): Structure and Function of Antarctic Terrestrial Ecosystems. Book of Abstracts and Contributed Papers. Conference, Brno, October 22th-23th, 2009. Masaryk University, Brno, p. 33-34.

Pizarro, H., Vinocur, A. (2000): Epilithic biomass in an outflow stream at Potter Peninsula, King George Island, Antarctica. Polar Biology, 23: 851-857.

Sutherland, D.L., Hawes, I. (2009): Annual growth layers as proxies of past growth conditions for benthic microbial mats in a perennially ice-covered Antarctic lake. FEMS Microbiology Ecology, 67: 279-292.

Toro, M., Camacho, A., Rochera, C., Rico, E., Bańón, M., Fernández-Valiente, E., Marco, E., Justel, A., Avendańo, M.C., Ariosa, Y., Vincent, W.F. and Quesada, A. (2006): Limnological characteristics of the freshwater ecosystems of Byers Peninsula, Livingston Island, in maritime Antarctica. Polar Biology, 30: 635-649.

Váczi P., Barták, M. (2009): Variability of oxygen content in different lakes of the James Ross Island as dependent on actual weather conditions. In: M. Barták, J. Hájek, P. Váczi (eds.): Structure and Function of Antarctic Terrestrial Ecosystems. Book of Abstracts and Contributed Papers. Conference, Brno, October 22th-23th, 2009. Masaryk University, Brno, p. 30-32.

Vincent, W.F. Castenholz, R.W. Downes, M.T. and Howard-Williams, C. (1993): Antarctic cyanobacteria: light, nutrients and photosynthesis in the microbial mat environment. Journal of Phycology 29: 745-755.

Wharton Jr., R.A., McKay, C.P., Simmons Jr., G.M. and Parker, B.C. (1986): Oxygen budget of a perennially ice-covered Antarctic lake. Limnology and Oceanography, 31: 437-443.

\section{Other sources}

Czech Geological Survey. 2009. James Ross Island - Northern Part. Topographic map $1: 25$ 000. First edition. Praha, Czech Geological Survey. ISBN 978-80-7075-734-5. 